\title{
Leverage Behaviour in the G-7 Countries and the Influence of Stock Returns
}

\author{
Ólafur Briem ${ }^{1}$
}

\begin{abstract}
The study addresses the capital structure readjustment process by comparing some theoretical predictions with statistical evidence from international data. Orthodox theories based on debt-ratio mean reversion are challenged by testing the hypothesis of debt-ratio target irrelevance and the proposition that institutional factors influence leverage behaviour. The results provide evidence for the dependence of market value debt-ratio on stock returns in all the G-7 countries. Ample corporate issuing is not used to counteract the effects of stock returns on capital structure. Firm specific characteristics supported by orthodox theories are found most applicable to the US, UK and Japan. The book-value debt ratio shows relative dependence on past values, although this is found to be less the case in the Anglo-American countries than in continental Europe. These results indicate that corporate management is not interested in market-based debt-ratio targets, book values may be of greater concern.
\end{abstract}

\section{Ágrip}

Greinin fjallar um skuldsetningu fyrirtækja og fjármögnun peirra og viðfangsefnið pað að leiða í ljós hvort fyrirtæki sýni viðleitni til að velja sér fast og fyrirfram ákveðið hlutfall skulda og eigin fjár. Samanburður er gerður á skráðum fyrirtækjum G-7 landanna sem er áhugaverður fyrir pær sakir að löndunum má skipta niður í tvo mismunandi flokka eftir stjórnunarháttum og eignarhaldi. Má ætla að hinar sígildu kenningar um fjármál fyrirtækja eigi frekar við um lönd par sem eignarhald er dreift og eða hlutafjármarkaðir eru stórir (Bretland, BNA og Japan). Niðurstöðurnar leiða í ljós að skuldahlutfall fyrirtækja er almennt flöktandi og tilviljunarkennd breyta sem er undir afgerandi áhrifum markaðsvirðis eiginfjár prátt fyrir að umfang fjármögnunar sé nægjanleg til að hafa stjórn á hlutfallinu. Pegar skuldahlutfall er miðað við bókfært virði eigin fjár er pað stöðugra yfir tíma en virðist samt ekki hafa tilhneigingu til að leita jafnvægis.

JEL flokkun: G32

Lykil hugtök: Capital structure; debt ratio; target adjustment; corporate governance;

1 The paper is based on a part of my M.S. thesis. I am indebted to Jan Bartholdy at the Aarhus School of Business and Gylfi Magnússon at the University of Iceland for their excellent supervision and Jesper Damkier at the Center for Analytical Finance, Aarhus School of Business, for his valuable support. Further thanks go to Ásgeir Jónsson, Jeffrey Cosser and an anonymous reader for helpful comments. 


\section{Introduction}

The capital structure literature exhibits a number of elaborate theories predicting firm leverage behaviour, of which most are consistent with the presence of a debtratio readjustment process. The trade-off theory has been justified on the grounds of numerous individual economic and sociological factors which give rise to an optimal debt-ratio target. The pecking-order theory indicates that debt-ratio mean reversion takes place over time under plausible conditions. In fact, until recently, the randomness of capital structure was not a topic of much concern due to the convincing empirical evidence in favour of a target. However, the development of theoretical models and their application on ever more detailed sets of data in recent years leave many questions unanswered.

This paper briefly reviews the literature and applies an international dataset to detect the factors that tend to dominate the debt ratio of publicly traded firms in the G-7 countries. The study draws on a few papers which have recently attracted attention by introducing new dimensions and controversies into the literature of capital structure. Welch (2004) challenges the static trade-off theory by finding evidence in the US contradicting the widespread assumption that the debt ratio readjusts to specific targets when offset by external forces. He introduces the "implied debt ratio" to observe the relevance of stock returns in time-contingent debt-ratio movements. He shows how stock returns tend to push market value debt ratios away from their previous levels and how lively debt and equity issuing activity is not managed to counteract such deviations. Secondly, Rajan and Zingales (1995) and others find some inconsistencies between theoretical prediction and leverage across countries due to differences in institutional arrangements between countries. Thirdly, part of the controversies stem from the behavioural finance literature. Baker and Wurgler (2002) cast doubt on the existence of a pecking order of financing by maintaining that market timing and equity issuing is a prominent method of financing, although capital markets are generally considered efficient. These findings are supported by Graham and Harvey (2001) and also Frank and Goyal (2003), who detect lively equity issuing in the US capital markets. This paper will touch on these three controversial topics more or less. As the paper is focused on cross-country comparisons, there are certain institutional aspects to bear in mind. Orthodox theories are limited by being "subject" to the Anglo-American marketoriented environment. Conflicts between stakeholders are particularly relevant in such a setup, due to dispersed ownership and the asymmetry of information transmission in financial markets. Where those features are dampened or blurred by a different financial infrastructure, theoretical predictions might become biased. By referring to the corporate governance literature, the G-7 countries should provide an interesting comparison with a representative spread containing both market-oriented and bank-oriented countries².

2 The market-oriented countries, the UK, US and Canada, are characterized by large developed financial markets, whereas France, Italy and Germany rely more on bank financing. (Japan can be fitted to both groups depending on criteria). The corporate governance literature distinguishes between countries in such a way by referring to 
To summarize the capital structure issues tackled by this paper, they can be presented as the following hypotheses for testing: (i) The hypothesis of target irrelevance. The debt ratio shows no tendency to readjust to prior values or a fixed target because it is dominated by the influence of stock returns. Any debt ratio is as good as any other. (ii) The ample issuing hypothesis. Corporate issuing activity is sufficient to counteract the influence that stock returns have on the debt ratio, but management chooses not to use it. (iii) The stock-return hypothesis. Amongst firm characteristics, stock returns dominate other profitability measurements in terms of significance and effects on leverage behaviour. (iv) The target-irrelevance model hypothesis. The implied debt ratio is the only relevant debt-ratio determinant because it is driven by stock returns and the actual debt ratio is allowed to fluctuate accordingly, i.e. in a one-to-one relationship. (v) The corporate-governance hypothesis. Cross-country institutional differences have implications for the theoretical predictions of capital structure. The trade-off model shows greater resistance against the target-irrelevance model within the market-oriented countries and Japan. (vi) The ranking hypothesis. The economic impact of the implied debt ratio should increase when narrowing the debt definition towards long-term debt. This is because short-term debt is considered to facilitate more counteracting potentials than long-term debt. Debt-to-capital book value is least prone to stockreturn influence by definition and nature. (vii) The book-value hypothesis. The book-value debt ratio of the market-oriented countries shows less target persistence and more stock-return dependence. Accounting statements in the market-oriented countries are important signalling documents and are better connected to market values than those in the bank-oriented countries. Further, if equity issuing is dependent on market timing, there should be stronger correlation between the book and market values of the debt ratios.

The results imply that there is considerable corporate issuing amongst publicly traded firms, but it is not devoted to debt-target adjustments in any of the G-7 countries. The theoretical factors provided by conventional theories to explain debtratio movements, e.g. firm characteristics, are influential but become trivial in comparison to the significance of stock returns. Some institutional effects are noted, both influencing the method of financing and the behaviour of book-value debt ratio.

\section{Motives for capital structure management}

In recent years, conflicts between capital structure theories have progressed, both with respect to the existence of a target equilibrium and the debt-ratio adjustment process. This section will briefly address these issues in the light of conventional and recent theories provided by the literature.

institutional arrangements and their effects on shareholder conflicts through ownership and control. 


\subsection{Capital structure management with a target}

A number of theories in modern capital-structure literature suggest the existence of an optimal debt-ratio target, derived from weighing benefits of debt against costs. Together they give rise to the trade-off theory. Firstly, Ross (1977) suggests tradeoffs between benefits and costs of debt derived from agency costs of asymmetric information. The debt ratio serves the purpose of signalling information to the financial markets about the debt capacity of the firm, i. e. the firm's true value, in a manner introduced by Spence (1973). Leyland and Pyle (1977) use same setup to show how the entrepreneur signals the true worth of his project, but by means of opposite signs, i.e. increasing equity ratio instead of debt value. The second type of trade-off stems from agency costs of shareholder and manager conflicts as introduced by Jensen and Meckling (1976) and Jensen (1986). Managers are considered to act in their own interest by consuming perquisites and ploughing idle cash into mature businesses for empire building, resulting in "organisational inefficiencies". Here debt would trim the firm of idle cash and place constraints on perks. Thirdly, there are trade-offs from agency costs of shareholder and creditor conflicts, e.g. under-investment and other shareholder temptations to fool creditors by "playing games" 3 . Finally, in addition to the agency costs, trade-off theories are further supported by weighing the benefits of interest tax shields against bankruptcy costs of financial distress. Although the role of taxes is thoroughly underpinned by the trade-off theory, empirical work does not seem to bear it out convincingly. ${ }^{4}$

\subsection{Capital structure management without a target}

Two capital-structure theories of interest challenge the trade-off theory. A crucial ingredient of the pecking-order theory advocated by Myers and Majluf (1984) is insiders' preoccupation with the stock price and a resulting interaction between insiders and the stock market. Due to asymmetric information, financing decisions can be ordered according to their effects on the stock price through interpretation of signals. The ranking or pecking order favours internal financing through reinvested earnings, as this has the most favourable effect on the stock price. However, new debt issues are of secondary importance and equity issue is the least attractive method, as external financing is considered to exert negative effects on stock price. What is more, the pecking-order theory explains why the tax shield, as a motivation for debt accumulation, as discussed earlier, is of secondary importance. The financial slack is used to pay off debt, whereas deficits call for issuance of the safest security first and equity financing as a last resort. Hence, there is no target adjustment in the short run because leverage is correlated with the cash flow. Yet, if investments are lumpy and positively serially correlated and the business cycle systematic, there will be strings of years bringing financial deficits and surpluses. Under such conditions,

3 Myers (1977) describes the hazards of under-investment. Brealy and Myers (2003, p. 505) mention a number of motives for playing games, e.g. "risk shifting", "no added equity", "cash in and run", "bait and switch" and "playing for time".

4 For example Miller (1977) and Harris and Raviv (1991) discuss tax effects on these lines. A tax variable was tried in several regression specifications to explain leverage, but without success (see Section 6.1). 
debt ratios will not follow a random walk but rather mean-reversion, and the targetadjustment model will consequently turn out to be appropriate, even though no target exists.

The other theory of interest is a recent study which presents capital structure as a random variable, somewhat in line with the interpretations of Modigliani and Miller (1958). Welch (2004) shows how the market value debt-ratio fluctuates in accordance with stock returns, as if the preferred target were stock-price dependent, i.e. no particular fixed target exists. However, some limited debt-ratio reversion is found to take place towards previous historical debt-ratio values over long periods. A number of theoretical suggestions are presented. Firstly, the apparent lack of a target optimum corresponds with the pecking-order predictions. If there is correlation between cash balance and stock price, the readjustment inertia could be explained by the pecking order. However, stock price is more often psychological and random, whereas flow of funds and financial slack tends to be serially correlated (Myers (2003)). Secondly, asymmetric behaviour on the upside and downside of stock-price movements could result in random movements of debt ratio over time. On the upswing, management may refrain from issuing rebalancing debt due to entrenchment, whilst during the downswing, management avoids issuing rebalancing equity since it is regarded as undervalued. Thirdly, readjustment inertia could be provoked by high transaction costs of refinancing, in the wake of continuous debt-ratio fluctuations. However, this is doubtful, as refinancing is relatively cheap. According to Graham and Harvey (2001), transaction costs are not viewed as obstacles by firms. Fourthly, their survey indicates that "financial flexibility" and "credit rating" are the primary debt-policy factors in US firms. Such motives and many more found in their survey are inconsistent with active target readjustment and could account for random debt ratio. Finally, inefficient markets and irrational or behavioural factors might overrule target adjustments and provoke the observed adjustment inertia. In that sense, many factors can be contributing at the same time, e.g. market timing (Baker and Wurgler 2002) and irrational behaviour (Benartzi and Thaler 2001).

\subsection{The target-adjustment process}

Having reviewed theoretical propositions for the time-contingent movements of the debt ratio, the next step is to see how they fit the target-adjustment model:

$$
\Delta \mathrm{D}_{\mathrm{it}}=\alpha+\gamma\left(\mathrm{D}_{\mathrm{it}}{ }^{*}-\mathrm{D}_{\mathrm{i}, \mathrm{t}-1}\right)+\varepsilon_{\mathrm{it}}
$$

Shyam-Sunder and Myers (1999) explain within this framework how the management of a firm (i), can maintain the firm's capital structure at the optimal debt-ratio level at all times $\left(\mathrm{Dit}^{*}{ }^{*}\right)$. Should a random shock, e.g. an unexpected stockprice movement, occur and push the capital structure $\left(\mathrm{D}_{\mathrm{it}}\right)$ away from the optimum, the management can ensure readjustment. The speed of readjustment is reflected by the coefficient " $\gamma$ ". The optimal debt level is, however, unobservable. If it is assumed to be dependent on lagged values, the debt will have a mean-reverting behaviour: it 
will tend to bounce back to a mean value. Instantaneous target adjustment, if $\gamma=1$, is an interesting special case of equation (1):

$$
D_{\text {it }}=\alpha+D_{i t}{ }^{*}+\varepsilon_{i t} \Rightarrow D_{i t}=D_{i t}{ }^{*} ; \text { if } \alpha=E\left(\varepsilon_{i t}\right)=0
$$

This result hinges on the assumption that the adjustment is instantaneous, the intercept being zero and the random term being white noise. Restrictions on the adjustment coefficient have implications. If the adjustment coefficient is negative, firms will move away from target equilibrium. If $0<\gamma<1$, then the adjustment process is gradual, indicating the influence of adjustment costs. Such costs are weighed against the cost of deviating from the target optimum, giving rise to an optimal speed of adjustment. The trade-off theory translates quite neatly to an empirical model of cross-sectional analysis through the target-adjustment model. At the optimal debt-ratio level $\left(D_{i t}{ }^{*}\right)$, the advantages of borrowing and costs of financial distress would be balanced off at the margin. With reference to equation (2), firm " $\mathrm{i}$ " should be expected to operate, on average, at or close to $\mathrm{D}_{\mathrm{it}}{ }^{*}$ at time $t$. The trade-off theory specifies different optimal levels, dependent on different firm-specific characteristics. In that way it can be used cross-sectionaly to explain leverage behaviour as a function of observable firm characteristics or proxies ( $Z_{i t}$ ), (being approximations for theoretical factors):

$$
D_{\text {it }}^{*}=\beta Z_{\text {it }}
$$

By inserting (3) into (2) we get:

$$
\mathrm{D}_{\mathrm{it}}=\alpha+\beta Z_{\mathrm{it}}+\varepsilon_{\mathrm{it}} ; \gamma=1
$$

Thus, the trade-off theory predicts, in addition to the mean reversion debt-ratio behaviour over time, that there is a cross-sectional relationship between debt ratios and those factors that affect the costs and benefits of leverage. It predicts that firms with a lot of taxable profits, little growth and investment opportunities but a lot of tangible assets will prefer relatively high debt ratios. Accordingly, the debt ratio is presumed to correlate with profits, tax rates, tangible assets and business risk. These factors, and many more provided by the literature, are represented as firm-specific characteristics $\left(Z_{i t}\right)$ in equation (4).

Shyam-Sunder and Myers (1999) challenge the target hypothesis implied by the trade-off theory within this framework by detecting some mean reversion as a result of the pecking order. In comparison, Welch (2004) proposes little reversion: stock returns automatically work the debt ratio up or down, through the market value of equity (in the debt ratio's denominator), because the management does not counteract its influence on the capital structure. The debt ratio, fully influenced under such conditions, is defined as the "implied debt ratio" $\left(\mathrm{D}^{\mathrm{I}}\right)$ and the influence is of primary importance. The target-irrelevance theory centres on rejecting a causal relationship between the debt ratio and firm-specific characteristics. The trade-off theory's interpretation of such causal relationship is regarded as a type - II error, i.e. it is perceived to mistakenly "pick up" the effects of other, non-trade-off factors through firm characteristics ${ }^{5}$. The error is generated by the correlation of firm 5 Shyam-Sunder and Myers (1999) deal with a type - II error too. They find debt-ratio mean
reversion in their sample but attribute their findings neither to the trade-off theory nor as 
characteristics with the stock-return-induced debt ratio and the firm characteristics are thus wrongly valued as determinants of the debt ratio. The fact is, that whilst the trade-off theory assumes stable and targeted debt ratios for each individual firm, based on firm characteristics $\left(\beta Z_{i t}\right)$, they are in fact randomly dependent on the stockreturn-induced debt ratio (i. e. the implied debt ratio, $\beta \mathrm{D}_{\mathrm{it}}^{\mathrm{I}}$ ).

Debt-ratio dependence on the implied debt ratio, fitted within (1), results in:

$$
\begin{gathered}
\Delta \mathrm{D}_{\mathrm{it}}=\alpha+\gamma\left(\beta \mathrm{D}_{\mathrm{it}} \mathrm{I}^{\mathrm{I}}-\mathrm{D}_{\mathrm{i}, t-1}\right)+\varepsilon_{\mathrm{it}} ; \text { where } \mathrm{D}_{\mathrm{it}}{ }^{*}=\beta \mathrm{D}_{\mathrm{it}} \mathrm{I}^{\mathrm{I}} \\
\mathrm{D}_{\mathrm{it}}=\alpha+\beta \mathrm{D}_{\mathrm{it}}{ }^{\mathrm{I}}+\varepsilon_{\mathrm{it}} ; \text { a deduced form if } \gamma=1
\end{gathered}
$$

The target-adjustment model can be empirically estimated and used to test for the nature of debt-ratio readjustments by solving (5) as shown by (7):

$$
\mathrm{D}_{\mathrm{it}}=\alpha+\gamma \beta \mathrm{D}_{\mathrm{it}}^{\mathrm{I}}+(1-\gamma) \mathrm{D}_{\mathrm{i}, \mathrm{t}-1}+\varepsilon_{\mathrm{it}} ;
$$

If $\gamma=0$, the debt ratio will be stable and fixed, on average, around a historical mean, but if $\beta=\gamma=1$, the debt ratio will spontaneously adjust to a randomly driven equity term in the debt ratio and no mean reversion will emerge. Note that both the tradeoff model (4) and the stock-return-induced debt-ratio model (6) suggest that $\gamma=1$. Yet they tell completely different stories, and nesting one model within the other compares their relative importance by collecting the sum of (4) and (6):

$$
D_{\text {it }}=\alpha+\beta_{1} Z_{i t}+\beta_{2} D_{i t}{ }^{I}+\varepsilon_{i t}
$$

\section{A formal framework for analysis}

The foundations for empirical testing need to be elaborated. The structure is based on Welch (2004), with some variants, and is to be applied to an international dataset. The main concern is to see whether actual debt ratios behave as though firms, on average, readjust their debt ratios to previous levels or to a static target. If this is not the case, attention is drawn to the effects of stock prices and whether the capital structure is allowed to fluctuate accordingly. Thus the factors of interest can be incorporated within the target-adjustment model (1) and presented in the following estimation equation, as suggested in (7):

$$
D_{t+k}=\beta_{1}+\beta_{2} D_{t}+\beta_{3} D_{t, t+k}^{I_{t}}+\varepsilon_{t+k}
$$

The term $D_{t}$ is the actual firm debt ratio at time $t$, defined as the book value of debt $\left(d_{t}\right)$ divided by the book value of debt plus the market value of equity $\left(e_{t}\right)$ :

$$
D_{t}=d_{t} /\left(e_{t}+d_{t}\right)
$$

The term $\mathrm{D}_{\mathrm{t}, t+\mathrm{k}}$, is the implied debt ratio, which is relevant when no corporate issuing takes place over the time period from $t$ to $t+k$. In other words $d$ and e have their fixed values from time $t$ whilst the sole varying factor over the period $t+k$ in the $\mathrm{D}_{\mathrm{t}, \mathrm{t}+\mathrm{k}}$ is the stock return $(\mathrm{x})$ :

$$
\mathrm{DI}_{\mathrm{t}, \mathrm{t}+\mathrm{k}}=\mathrm{d}_{\mathrm{t}} /\left(\mathrm{et}_{\mathrm{t}}\left(1+\mathrm{xt}_{\mathrm{t}, \mathrm{t}+\mathrm{k}}\right)+\mathrm{d}_{\mathrm{t}}\right)
$$

evidence for the existence of a target. They find the pecking order at work and argue that in view of the low power of the trade-off model, it usually attracts statistically more attention than it deserves. 
There are two competing hypotheses nested within (9): A perfect debt-ratio readjustment, over the time period $\mathrm{t}+\mathrm{k}$ in the wake of deviating stock-price effects, is supported by: $\beta_{2}=1$ and $\beta_{3}=0$. On the other hand there can be a total lack of readjustment, with $\beta_{2}=0$ and $\beta_{3}=1$. The intention of including the constant $\beta_{1}$ in equation (9) is to capture the effects of a constant non-changing target debt ratio over the time period $t+k$. If the target debt ratio were constant, the scenario would change to $\beta_{1}=1, \beta_{2}=0$ and $\beta_{3}=0$.

The corporate issuing activity which generates the dynamics of the capital structure and underlies equation (9) is represented by debt changes and equity changes over the time period $\mathrm{t}+\mathrm{k}$. The debt amount changes over time with new debt issues, debt retirements, coupon payments and debt-value changes, and can be represented by $\Delta \mathrm{d}_{\mathrm{t}, \mathrm{t}+\mathrm{k}}$ (total debt net issue):

$$
\mathrm{d}_{\mathrm{t}+\mathrm{k}}=\mathrm{d}_{\mathrm{t}}+\Delta \mathrm{d}_{\mathrm{t}, \mathrm{t}+\mathrm{k}}
$$

In a similar manner, the amount of corporate equity issuing activity can be represented by $\Delta \mathbf{e}_{t, t+k}$ (net equity issuing), incorporating equity changes driven by new equity issues net of equity repurchases 6 :

$$
\mathrm{e}_{\mathrm{t}+\mathrm{k}}=\mathrm{e}_{\mathrm{t}}\left(1+\mathrm{x}_{\mathrm{t}, \mathrm{t}+\mathrm{k}}\right)+\Delta \mathrm{e}_{\mathrm{t}, \mathrm{t}+\mathrm{k}}
$$

Hence, the dynamic underlying equation (9) becomes:

$$
\mathrm{D}_{\mathrm{t}+\mathrm{k}}=\left(\mathrm{d}_{\mathrm{t}}+\Delta \mathrm{d}_{\mathrm{t}, \mathrm{t}+\mathrm{k}}\right) /\left(\mathrm{e}_{\mathrm{t}}\left(1+\mathrm{x}_{\mathrm{t}, \mathrm{t}+\mathrm{k}}\right)+\Delta \mathrm{e}_{\mathrm{t}, \mathrm{t}+\mathrm{k}}+\left(\mathrm{d}_{\mathrm{t}}+\Delta \mathrm{d}_{\mathrm{t}, \mathrm{t}+\mathrm{k}}\right)\right)
$$

The structure of analysis is naturally incorporated within the target-adjustment model and as a result some restrictions will be imposed on the variable coefficients. By feeding the details of equations (9)-(14) into the target-adjustment model (1), we obtain:

$$
\begin{gathered}
\Delta D_{t+k}=\alpha+\gamma\left(D_{t+k}^{*}-D_{t}\right)+\varepsilon_{t+k} \\
D^{*}{ }_{t+k}=\beta_{1}+\beta_{3} D^{I_{t, t+k}} \\
\Delta D_{t+k}=\alpha+\gamma \beta_{1}+\gamma\left(\beta_{3} D_{t, t+k}^{I_{t}}-D_{t}\right)+\varepsilon_{t+k} \\
D_{t+k}=\left(\alpha+\gamma \beta_{1}\right)+(1-\gamma) D_{t}+\gamma \beta_{3} D_{t, t+k}+\varepsilon_{t+k}
\end{gathered}
$$

Note that $\mathrm{D}_{\mathrm{t}+\mathrm{k}}^{*}$ is assumed to be partially dependent on $\mathrm{D}^{\mathrm{I}}$, being $\beta_{3} \mathrm{D}_{\mathrm{t}, t+\mathrm{k}}^{\mathrm{I}}$. By setting $\beta_{3}=1, D^{I}$ becomes the target and the instantaneous adjustment process $(\gamma=1)$ produces a random outcome within the target-adjustment model:

$$
\begin{gathered}
\Delta \mathrm{D}_{\mathrm{t}+\mathrm{k}}=\alpha+\gamma \beta_{1}+\gamma\left(\mathrm{D}_{\mathrm{t}, \mathrm{t}+\mathrm{k}}-\mathrm{D}_{\mathrm{t}}\right)+\varepsilon_{\mathrm{t}+\mathrm{k}} \\
\mathrm{D}_{\mathrm{t}+\mathrm{k}}=\alpha+\beta_{1}+\mathrm{D}_{\mathrm{t}, \mathrm{t}+\mathrm{k}}+\varepsilon_{\mathrm{t}+\mathrm{k}} ; \text { if } \gamma=1
\end{gathered}
$$

In other words, the random behavior of the defined target, along with speedy adjustments, does not imply mean reversion or readjustment to a historical mean as characterised by the trade-off model. On the contrary, the opposite is detected, a randomly fluctuating debt ratio, with no relation to the historic mean. This phenomenon should be observed if management is perfectly satisfied with the

6 Although equations (12) and (13) are not of relevance in the estimation procedures to follow, they are enlightening as descriptive statistics and when contrasting corporate issuing activity with the stock- return-induced equity for counteracting potentials. 
continuous variation of the market value of debt ratio and is only concerned with other aspects of financing.

The trade-off theory assumes that firms operate at or near their target optimum. This is why the theory predicts cross-sectional debt-ratio correlation with firm-specific characteristics. The target-readjustment implications of the trade-off theory can be challenged again in a different way from (9) by taking account of the firm-specific characteristics. By nesting $\mathrm{D}^{\mathrm{I}}$ amongst the trade-off-influencing firm-specific factors, its relative importance can be compared with the other elements of the trade-off model:

$$
D_{t+k}=\beta_{1}+\beta_{2} Z_{t+k}+\beta_{3} D_{t, t+k}^{I_{t}}+\varepsilon_{t+k}
$$

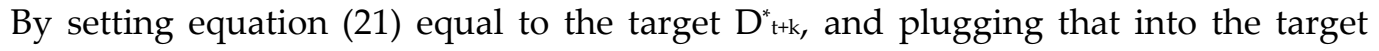
adjustment model (15), we obtain:

$$
\Delta \mathrm{D}_{\mathrm{t}+\mathrm{k}}=\left(\alpha+\gamma \beta_{1}\right)+\gamma\left(\beta_{3} \mathrm{D}_{\mathrm{t}, \mathrm{t}+\mathrm{k}}-\mathrm{D}_{\mathrm{t}}\right)+\gamma \beta_{2} \mathrm{Z}_{\mathrm{t}+\mathrm{k}}+\varepsilon_{\mathrm{t}+\mathrm{k}}
$$

As can be seen, if $\beta_{3}=1$, the coefficient of $D^{I}$ is restricted in this specification by $\gamma$. Further, the target-adjustment model restricts the importance of the trade-off proxies by the adjustment speed $\left(\gamma \beta_{2} Z_{\mathrm{t}+\mathrm{k}}\right)$. This specification needs $\beta_{3}=\gamma=1$ to support a hypothesis of a random target.

\section{The Data}

Thomson's DataStream was the main provider of statistical information, most importantly by supplying the Worldscope balance sheet data. An advantage of this choice was a relatively broad selection of time-series data stemming from a large number of firms in a single data source. Another advantage was the comparative quality of the data supplied with regard to differences in accounting standards. Furthermore, as Welch (2004) and Rajan and Zingales (1995) used Compustat, trying a different data source for the same purpose was considered a more interesting challenge.

The data sample period spans 24 years, from 1980 to 2003, and contains all publicly traded non-financial firms in the G-7 countries. The number of sample firms increased steadily over the sample period and the contrast between market- and bank-oriented countries is clearly reflected by the contrast of sample size. In the year 2002 the former group consisted of the US, with 5,797 sample firms and the UK, with 1,334, and the second consisted of France, with 661 sample firms, Italy, with 194 and Germany with 619. Technically Japan can be ranked with the former group when considering the size of the stock market, with 3,104 firms. Canada provided 841 firms. Different corporate governance systems are reflected through these figures and indeed in the number of firm-years, which will be referred to in the statistical tables. 
The accounting definition of debt may vary between the G-7 countries, and therefore we must rely somewhat on Datastream's data handling for comparability ${ }^{7}$ The selection of the relevant leverage measurement depends on what we want to interpret and data availability. The literature offers a number of options but a widely-accepted definition is that of debt to capital. The data source allowed three broad ways of measuring debt without sacrificing many observations, involving combinations of long-term debt, short-term debt and current liabilities. This study uses the ratio of long-term debt plus current liabilities to market value of capital. Both the numerator and denominator of the ratio can be exchanged for other alternative proxies incorporating the marginal benefits and costs of leverage. However, the chosen definition can be justified by being well accepted in the literature and results will be tested by other definitions for robustness.

\section{Target irrelevance vs. target adjustment}

The data will first be used to investigate the target irrelevance and ample issuing hypothesis (i) and (ii).

\subsection{Descriptive statistics}

Table 1 displays some descriptive statistics. The rows present normalized means of debt and equity financing, with the respective standard deviation stated below each mean $^{8}$. Starting at the top of the table, we find the means and medians of the actual and implied debt ratios for the one-year horizon. The implied debt ratio does not deviate far from the actual debt ratio; however, in all cases except for that of Japan, the implied ratio deviates to lower values for the five-year horizon. Perhaps a consequence of low stock returns in Japan might explain why Japanese firms are the most levered in the G-7 countries. Another feature characterizing the Japanese firms is the low degree of standard deviation of the implied debt ratio. In fact, debt and equity issuing activity is also exceptionally low in Japan. The normalized net debt issue, on average, is only about $6 \%$ for the 5 -year horizon and the total net issuing $8.6 \%$, compared to a value generally around $30 \%$ and $50 \%$ respectively for the other countries. Germany is closest to the Japanese case as regards both issuing activity and low levels of return-induced equity growth, although there is a considerable difference in the debt-ratio levels. This applies both to the one-year and the five-year horizons. Whether a result of similar bank relations, economic climate or sheer coincidence, the uniformity stands out. The low degree of issuing over the sample period for the two countries could reflect constraints in the wake of economic stagnation, low investment levels and disappointing prospects (low returns) confronting banks.

\footnotetext{
7 Rajan and Zingales (1995) suggest methods to improve the comparative quality of the Compustat data, which seem to be consistent with the data definitions of Datastream.

8 The means are normalized by firm market values and trimmed of outliers between the $1^{\text {st }}$ and $99^{\text {th }}$ percentile for the one-year case and $5^{\text {th }}$ and $95^{\text {th }}$ percentile for the five-year case.
} 
Table 1. Selected Descriptive Statistics in \%. Cross-Country Comparison

\begin{tabular}{|c|c|c|c|c|c|c|c|c|}
\hline Abbreviation & One-year description & US & Japan & Germany & France & Italy & UK & Canada \\
\hline \multirow[t]{3}{*}{$D_{t}$} & Past debt ratio & 37.4 & 49.0 & 41.6 & 47.3 & 43.5 & 38.5 & 38.2 \\
\hline & (median) & 33.7 & 49.2 & 40.1 & 47.7 & 45.0 & 36.3 & 35.7 \\
\hline & & 26.1 & 22.6 & 25.2 & 24.3 & 29.9 & 21.7 & 26.5 \\
\hline \multirow[t]{3}{*}{$D_{t, t+1}^{I}$} & Implied debt ratio & 38.0 & 49.2 & 42.3 & 47.3 & 42.8 & 38.6 & 38.6 \\
\hline & (median) & 33.5 & 49.4 & 40.5 & 47.1 & 45.0 & 35.4 & 35.1 \\
\hline & & 27.1 & 22.8 & 25.6 & 24.9 & 29.9 & 22.6 & 27.2 \\
\hline$d_{t}+e_{t}$ & \multicolumn{8}{|c|}{ Normalized by market value } \\
\hline \multirow[t]{2}{*}{$\Delta \mathrm{d}_{\mathrm{t}, t+1}$} & Net debt issue & 3.2 & 0.6 & 3.0 & 5.0 & 5.4 & 3.5 & 5.0 \\
\hline & & 12.5 & 9.3 & 19.8 & 22.8 & 18.7 & 32.6 & 23.8 \\
\hline \multirow[t]{2}{*}{$\Delta e_{t, t+1}$} & Net equity issue & 2.7 & -1.0 & -0.9 & 1.0 & 7.5 & 3.6 & 6.8 \\
\hline & & 12.1 & 25.8 & 42.3 & 24.4 & 14.8 & 48.6 & 48.5 \\
\hline \multirow[t]{2}{*}{$\Delta \mathrm{d}_{\mathrm{t}, \mathrm{t}+1}+\Delta \mathrm{e}_{\mathrm{t}, \mathrm{t}+1}$} & Debt and equity issuing & 7.8 & -0.5 & 2.9 & 6.0 & 6.2 & 7.2 & 11.8 \\
\hline & & 25.4 & 27.6 & 46.4 & 34.0 & 24.5 & 66.4 & 55.7 \\
\hline \multirow[t]{2}{*}{$e_{t}\left(1+x_{t, t+1}\right)$} & Stock return & 7.5 & 2.4 & 2.0 & 5.1 & 3.6 & 7.8 & 9.5 \\
\hline & & 39.3 & 32.5 & 35.1 & 34.2 & 31.9 & 39.6 & 50.6 \\
\hline Abbreviation & Five-year description & US & Japan & Germany & France & Italy & UK & Canada \\
\hline \multirow[t]{3}{*}{$D_{t, t+5}^{I}$} & Implied debt ratio & 36.2 & 50.7 & 41.6 & 43.0 & 37.5 & 36.7 & 38.8 \\
\hline & (median) & 28.6 & 51.0 & 38.0 & 40.1 & 35.4 & 30.4 & 33.7 \\
\hline & & 28.9 & 23.4 & 27.1 & 26.7 & 31.3 & 25.1 & 27.3 \\
\hline$d_{t}+e_{t}$ & \multicolumn{8}{|c|}{ Normalized by market value } \\
\hline \multirow[t]{2}{*}{$\Delta \mathrm{d}_{\mathrm{t}, \mathrm{t}+5}$} & Net debt issue & 27.3 & 5.9 & 20.1 & 34.4 & 39.7 & 35.7 & 36.0 \\
\hline & & 54.2 & 23.0 & 78.6 & 84.3 & 96.9 & 114.2 & 76.9 \\
\hline \multirow[t]{2}{*}{$\Delta \mathrm{e}_{\mathrm{t}, \mathrm{t}+5}$} & Net equity issue & 13.8 & 2.7 & -1.7 & 5.8 & 8.5 & 20.0 & 35.0 \\
\hline & & 63.1 & 29.2 & 65.2 & 81.6 & 55.0 & 132.6 & 109.9 \\
\hline \multirow[t]{2}{*}{$\Delta \mathrm{d}_{\mathrm{t}, \mathrm{t}+5}+\Delta \mathrm{e}_{\mathrm{t}, \mathrm{t}+5}$} & Debt and equity issuing & 48.8 & 8.6 & 20.2 & 40.2 & 48.2 & 55.7 & 71.0 \\
\hline & & 122.2 & 40.0 & 107.3 & 118.0 & 123.2 & 219.4 & 154.0 \\
\hline \multirow[t]{2}{*}{$e_{t}\left(1+x_{t, t+5}\right)$} & Stock return & 46.5 & -0.5 & 23.5 & 40.0 & 33.9 & 44.3 & 32.6 \\
\hline & & 103.2 & 53.1 & 82.1 & 108.1 & 91.2 & 119.5 & 117.0 \\
\hline
\end{tabular}


Apart from these two cases there is a general resemblance among the G-7 countries with respect to issuing and total return. First, the stock-return is around $6 \%$ of firm market value for the one-year horizon, with the market-oriented economies showing greater returns (around 8\%) compared to the bank-oriented ones (3\%). This value generally reaches $20 \%$ to $45 \%$ for the five-year horizon, again reflecting roughly the same pattern between the two groups. Secondly, debt issuing, which is by definition net of gross issuing and retirement of debt, seems in most cases to centre around $4 \%$ for the one-year horizon and roughly $35 \%$ for the five-year horizon. Thirdly, net equity issuing is generally of less importance and exhibits greater variation between the countries, being most relevant for the market-oriented economies and least for the bank-oriented economies. Finally, in terms of collective net issuing activity, the G-7 countries present a mean value of about 7\% of firm market value for the one-year horizon and $50 \%$ for the five-year horizon, with Canada above average and Japan and Germany below. Again, the countries can be ordered into the same groups on the basis of total corporate issuing.

Issuing activity can be described both in terms of mean levels and standard deviation. Stock returns and issuing reach the same mean levels, and also show, to some extent, corresponding variability. This tells us, for example, that the stock-induced equity growth heterogeneity for the five-year horizon in the US, $103.2 \%$, is not far from the managerial-activity-induced heterogeneity of $122.2 \%$. Thus, there should be sufficient issuing activity in the US to counteract any stock-return fluctuations affecting the capital structure. The mean and standard deviation of total issuing activity of all the G-7 countries follow the stock-return-induced equity growth fairly closely, with notably greater standard deviation in the market-oriented economies. This can be seen as evidence for the ample-issuing hypothesis (ii) ${ }^{9}$.

We can conclude that although debt issuing activity does not seem to rank in any particular way, both equity issuing and total issuing activity seem to be of more importance in the market-oriented economies than in the bank-oriented countries. This corresponds both to the capital market size and also the stock returns of the G-7 countries. In other words, higher stock returns in the market-oriented countries might reflect economic progress and higher growth rates and therefore necessitate external financing, supported by larger financial markets. Furthermore, there is evidence of ample corporate issuing.

9 This hypothesis was also supported when corporate issuing was estimated by computing "internal debt ratio" variables, e. g.: $\mathrm{D}_{\mathrm{t}, \mathrm{t}+\mathrm{k}}^{\mathrm{c}}=\left(\mathrm{d}_{\mathrm{t}}+\Delta \mathrm{d}_{\mathrm{t}, \mathrm{t}+\mathrm{k}}\right) /\left(\mathrm{d}_{\mathrm{t}}+\Delta \mathrm{d}_{\mathrm{t}, \mathrm{t}+\mathrm{k}}+\mathrm{e}_{\mathrm{t}}+\Delta \mathrm{e}_{\mathrm{t}, t+\mathrm{k}}\right)$; for total issue $\left(D^{c}\right)$, etc. These were compared with the implied debt ratio $\left(D^{\mathrm{I}}\right)$ in terms of correlation with the actual debt ratio (D) by regressing $\mathrm{D}_{\mathrm{t}, t+\mathrm{k}}^{\mathrm{i}}$ on $\mathrm{D}_{\mathrm{t}}$, for $\mathrm{i}=\mathrm{I}, \mathrm{e}, \mathrm{d}$ and $\mathrm{c}$ as suggested by Welch (2004). 


\subsection{Testing for target irrelevance vs. target readjustment}

The target-adjustment process and the estimation of equation (9), i.e. results from the Fama-MacBeth regressions explaining future actual debt ratios $\left(\mathrm{D}_{\mathrm{t}+\mathrm{k}}\right)^{10}$, are displayed in Table 2. In general terms, similar characteristics are found for most of the G-7 countries, which supports the irrelevance hypothesis (i) confirmed by low constants $(\alpha)$ and low past debt-ratio (D) coefficients. Firms are reluctant to revert to their original actual debt ratio as reflected by the modest increase in $\alpha$ and D coefficients across the time horizon of five years. Firms allow their debt ratios to fluctuate with stock returns as reflected by the implied debt-ratio $\left(\mathrm{D}^{\mathrm{I}}\right)$ coefficients. This tendency is greater for the relatively short horizon, 1-3 years (around $70-90 \%$ correlation) but becomes weaker for longer horizons, 3-5 years (around 70\% and below), as can be noted from a drop in the $\mathrm{D}^{\mathrm{I}}$ coefficients. Accordingly, the actual debt ratio (D) gains significance and value with longer horizons, but only to a very limited degree. Furthermore, in competition with the constant, D also loses economic significance. The smaller $\mathrm{D}$ coefficient reflects a smaller desire on the part of firms to revert to their starting debt ratios than a tendency of firms to prevent debt ratios from wandering too far away from a fixed constant.

Table 2 reflects the same characteristic for most of the G-7 countries. However, two idiosyncratic features appear. First, the UK and the US have the highest constants for all horizons, representing the relative importance of a static debt ratio. They increase from a value around 5\% with regard to the one-year horizon up to one of around $15 \%$ in the five-year case. Second, the two countries show a particularly low and insignificant coefficient for the past debt ratio for all horizons (although incrementally increasing). In comparison, the two bank-oriented countries, Japan and Germany, display considerable readjustment during the one-year horizon but their features align with those of the other continental European countries for the three-year and five-year horizons. This relatively larger D coefficient $\left(\beta_{2}\right)$ for these countries could be a sign of a greater degree of debt readjustment represented by low-cost access to bank loans through bank relations. However, this explanation is not convincing, as the characteristic disappears over longer horizons. Moreover, Japan and Germany represent the only cases where the importance of past debt ratio and readjustment loses significance over extended horizons. Other countries, on the other hand, show some limited readjustment tendencies. For Japan and Germany, this could, on the one hand, reflect a shift in the optimal debt-ratio target in the interim. On the other hand, the high value of $\beta_{2}$ is conceivably observed by a lower variation in actual debt ratios compared to the variation in implied debt ratios. With respect to the relatively low level of return and issuing dynamics presented for Japan and Germany in Table 1, the latter possibility is more appealing. The Canadian firms seem more in line with those of Japan and Germany, so any explanation regarding readjustment motives is difficult on the basis of institutional characteristics.

10 The method is based on repeated cross-sectional regressions over the continuous time interval of the sample period. The coefficients presented are the means of those collected from each regression. 
Table 2. Fama-MacBeth Regressions Explaining Future Actual Debt Ratios $\left(\mathrm{D}_{\mathrm{t}+\mathrm{k}}\right)$. Estim. in \%.

\begin{tabular}{|c|c|c|c|c|c|c|c|c|}
\hline Abbreviation & One-year horizon & US & Japan & Germany & France & Italy & $\mathrm{UK}$ & Canada \\
\hline \multirow[t]{2}{*}{$\alpha$} & Constant & 4.0 & 2.3 & 2.7 & 4.1 & 2.4 & 6.1 & 4.9 \\
\hline & & 0.3 & 0.5 & 1.2 & 1.0 & 1.3 & 0.6 & 1.3 \\
\hline \multirow[t]{2}{*}{$D_{t}$} & Past debt ratio & -1.2 & 35.6 & 54.1 & 5.8 & 7.0 & -0.1 & 27.1 \\
\hline & & 1.8 & 3.4 & 9.5 & 6.1 & 15.4 & 3.8 & 8.8 \\
\hline \multirow[t]{2}{*}{$\mathrm{D}_{\mathrm{t}, \mathrm{t}+1}^{\mathrm{I}}$} & Implied debt ratio & 93.9 & 60.7 & 40.0 & 88.6 & 90.1 & 88.9 & 62.7 \\
\hline & & 1.8 & 3.4 & 9.4 & 6.0 & 15.6 & 3.7 & 8.7 \\
\hline $\mathrm{R}^{2}$ & Explanatory power & 89.4 & 91.4 & 88.2 & 92.9 & 94.6 & 88.9 & 82.3 \\
\hline $\mathrm{n}$ & No. of regressions & 23 & 23 & 23 & 23 & 23 & 23 & 23 \\
\hline $\mathrm{N}$ & Firm-years & 74,955 & 32,483 & 6,463 & 7,042 & 2,267 & 19,893 & 7,539 \\
\hline Abbreviation & Three-y & US & Japan & Germany & France & Italy & UK & Canada \\
\hline \multirow[t]{2}{*}{$\alpha$} & Constant & 10.0 & 5.3 & 7.2 & 9.6 & 6.9 & 14.7 & 10.3 \\
\hline & & 0.5 & 0.6 & 1.9 & 1.7 & 2.5 & 1.1 & 1.9 \\
\hline \multirow[t]{2}{*}{$D_{t}$} & Past debt ratio & -1.0 & 14.7 & 19.0 & 10.7 & 17.6 & -0.8 & 11.3 \\
\hline & & 1.9 & 2.8 & 9.0 & 6.1 & 16.7 & 3.9 & 7.7 \\
\hline \multirow[t]{2}{*}{$D_{t, t+3}^{I}$} & Implied debt ratio & 83.5 & 77.7 & 68.2 & 76.1 & 73.7 & 73.7 & 67.9 \\
\hline & & 1.8 & 2.9 & 8.8 & 5.9 & 17.1 & 3.7 & 7.4 \\
\hline $\mathrm{R}^{2}$ & Explanatory power & 74.6 & 85.4 & 76.2 & 82.6 & 84.1 & 66.1 & 67.6 \\
\hline $\mathrm{n}$ & No. of regressions & 21 & 21 & 21 & 21 & 21 & 21 & 21 \\
\hline $\mathrm{N}$ & Firm-years & 56,752 & 26,665 & 4,807 & 5,190 & 1,718 & 15,499 & 5,321 \\
\hline Abbreviation & Five- & US & Japan & Germany & France & Italy & UK & Canada \\
\hline \multirow[t]{2}{*}{$\alpha$} & Constant & 14.2 & 7.4 & 10.2 & 13.1 & 10.1 & 19.8 & 14.4 \\
\hline & & 0.6 & 0.8 & 2.6 & 2.5 & 3.5 & 1.3 & 2.5 \\
\hline \multirow[t]{2}{*}{$\mathrm{D}_{\mathrm{t}}$} & Past debt ratio & 1.6 & 11.5 & 14.1 & 14.1 & 19.0 & 1.1 & 13.5 \\
\hline & & 2.1 & 2.9 & 9.6 & 7.0 & 16.5 & 4.2 & 7.8 \\
\hline \multirow[t]{2}{*}{$\mathrm{D}_{\mathrm{t}, \mathrm{t}+5}^{\mathrm{I}}$} & Implied debt ratio & 74.9 & 77.5 & 68.4 & 66.6 & 65.6 & 62.3 & 58.1 \\
\hline & & 1.9 & 3.0 & 9.1 & 6.7 & 17.0 & 3.9 & 7.4 \\
\hline $\mathrm{R}^{2}$ & Explanatory power & 64.6 & 79.9 & 69.0 & 72.9 & 75.0 & 53.8 & 56.4 \\
\hline $\mathrm{n}$ & No. of regressions & 19 & 19 & 19 & 19 & 19 & 19 & 19 \\
\hline $\mathrm{N}$ & Firm-years & 41,114 & 21,246 & 3,580 & 3,696 & 1,292 & 11,862 & 3,568 \\
\hline
\end{tabular}




\section{The target irrelevance model vs. firm-specific characteristics}

The framework of analysis has until now been limited to two variables. This constraint will now be relaxed by adding alternative variables to test the stock-return hypothesis (iii), the target-irrelevance model (iv) and the corporate-governance hypothesis (v).

\subsection{Estimation with added explanatory variables}

Attempts made to distinguish between theoretical factors influencing debt ratio in empirical work have not proved fruitful. ${ }^{11}$ Therefore the customary methodology has focused on nested models, explaining leverage behaviour by using a variety of variables that can be justified on the grounds of any theory. Most variables are represented by trade-off theory firm-specific characteristics. In comparison to earlier cross-country studies, the specification to be presented uses larger samples, a longer observation period and a different methodology. The Fama-MacBeth cross-sectional regression method is applied to variables selected from DataStream with respect to those recommended by prior literature and their general availability over the sample period (see appendix). The estimation equation below distinguishes between flow variables $\mathrm{Vi}_{\mathrm{t}, t+\mathrm{k}}$ collected over the time period $\mathrm{t}$ to $\mathrm{t}+\mathrm{k}$ and stock variables $\mathrm{Vi}_{\mathrm{t}}$ :

$$
D_{t+k}-D_{t}=\beta_{1}+\beta_{2}\left(D_{t, t+k}-D_{t}\right)+\sum^{N_{i}}\left(\beta_{i} V_{t_{t, t+k}}\right)+\sum^{M_{j}}\left(\beta_{j} V_{t_{t}}\right)+\varepsilon_{t+k}
$$

Table 3 displays results which show how dominating the effects of the implied debt ratio are. Several specifications were tried, with and without the implied debt ratio, and all revealed similar features. Excluding the implied debt ratio, stock returns on their own were economically and statistically more influential than profits and indeed any other variable. The implied debt ratio however, supersedes the stock returns variable in terms of importance when introduced into the structure. It absorbs some of the significant features of both the flow and stock variables and improves the explanatory power on all occasions by 3-30 percentage points ${ }^{12}$. The market-oriented countries and Japan turn out to have more significance in terms of valid coefficients than other countries.

11 See e.g. Shyam-Sunder and Myers (1999) and Frank and Goyal (2003).

12 The improvement was smallest in the case of Germany (44\% variation explained), and greatest in the case of the US (59\% explained). 
Table 3. Regressions Explaining Debt Ratio Changes $\left(D_{t+k}-D_{t}\right)$ : Adding Variables

\begin{tabular}{|c|c|c|c|c|c|c|c|c|}
\hline \multicolumn{2}{|c|}{ Abbreviation One-year horizon } & \multirow{2}{*}{$\begin{array}{l}\text { US } \\
0.048^{* *}\end{array}$} & \multirow{2}{*}{$\begin{array}{l}\text { Japan } \\
0.116^{* * *}\end{array}$} & \multirow{2}{*}{$\begin{array}{r}\text { Germany } \\
0.091\end{array}$} & \multirow{2}{*}{$\begin{array}{r}\text { France } \\
0.092\end{array}$} & \multirow{2}{*}{$\begin{array}{l}\text { Italy } \\
0.090\end{array}$} & \multirow{2}{*}{$\begin{array}{l}\mathrm{UK} \\
0.083\end{array}$} & \multirow{2}{*}{$\begin{array}{r}\text { Canada } \\
0.098\end{array}$} \\
\hline (Constant) & Constant & & & & & & & \\
\hline \multicolumn{9}{|c|}{ Flow variables measured from $t$ to $t+k$ : } \\
\hline$D_{t, t+1}^{I}-D_{t}$ & Implied debt ratio & $0.966^{* * *}$ & $0.350 * * *$ & $0.165^{* *}$ & $0.936 * * *$ & $0.955^{* * *}$ & $0.977^{* * *}$ & $0.546^{* * *}$ \\
\hline LOGVOL1 & Return volatility & 0.000 & 0.000 & 0.001 & -0.002 & 0.000 & 0.000 & -0.001 \\
\hline SR1 & Stock return & 0.001 & $-0.046^{* * *}$ & $-0.048^{* * *}$ & 0.002 & 0.011 & 0.005 & $-0.014^{* *}$ \\
\hline PA1 & Profitability to assets & 0.008 * & $-0.085 *$ & -0.020 & 0.026 & -0.064 & $0.054^{* *}$ & -0.031 \\
\hline PS1 & Profitability to sales & 0.002 & 0.004 & -0.006 & 0.004 & 0.039 & 0.009 & 0.009 \\
\hline TAX1 & Tax rate & 0.000 & 0.003 & -0.003 & 0.002 & 0.001 & -0.001 & 0.005 \\
\hline \multicolumn{9}{|c|}{ Stock variables measured at $\mathrm{t}$ : } \\
\hline DEV1 & Industry deviation & $-0.063^{* * *}$ & -0.025 & -0.038 & $-0.039 *$ & -0.004 & $-0.079^{* * *}$ & $-0.080^{* *}$ \\
\hline TANG1 & Tangibility & $0.009 *$ & 0.004 & 0.015 & -0.003 & -0.010 & 0.003 & 0.005 \\
\hline LOGAS1 & Assets & $-0.008^{* *}$ & $-0.022 * * *$ & -0.016 & -0.012 & -0.022 & -0.013 & -0.021 \\
\hline LOGSALE & Size & 0.002 & $0.008^{*}$ & 0.006 & 0.003 & 0.008 & 0.005 & 0.007 \\
\hline LOGCAP1 & Market capitalization & $0.008^{* * *}$ & $0.015^{* * *}$ & 0.011 & 0.009 & 0.013 & 0.010 & 0.013 \\
\hline \multirow[t]{4}{*}{ MB1 } & Market to book ratio & $-0.004^{* * *}$ & $0.005^{* * *}$ & -0.001 & $-0.004 *$ & -0.002 & $-0.007^{* *}$ & 0.000 \\
\hline & $\mathrm{R}^{2}$ & 0.592 & 0.436 & 0.315 & 0.626 & 0.595 & 0.612 & 0.376 \\
\hline & No. of observations (N) & 59,112 & 24,714 & 4,738 & 4,446 & 1,081 & 15,240 & 5,292 \\
\hline & Cross-sectional regressions & 23 & 23 & 23 & 16 & 11 & 23 & 21 \\
\hline
\end{tabular}


This is especially relevant for the US and Japanese samples, which are by far the largest in terms of firm-years and numbers of regressions, followed by the UK. In contrast, the continental European countries have merely one or two significant variables. This seems to support the corporate-governance implications of hypothesis (v), that capital structure theory seems more relevant where institutions encourage dispersed ownership and active stock markets. ${ }^{13}$

It can be concluded that evidence has been found supporting hypotheses (iii), (iv) and (v). Stock returns absorb most influence from the profitability variables (iii). Most countries have a $\Delta \mathrm{D}^{\mathrm{I}}$ coefficient of $\beta_{2} \approx 1$ and a target-adjustment coefficient of $\gamma$ $\approx 1$, indicating a one-to-one relationship between $\Delta \mathrm{D}^{\mathrm{I}}$ and debt-ratio change, supporting the target-irrelevance model (iv). The firm characteristics proxies of the conventional theories have their main strongholds in the market-oriented countries (including Japan), thus supporting (v). The low $\Delta \mathrm{D}^{\mathrm{I}}$ coefficients of Japan, German and Canada are explained by the significant past debt ratio that is now included in the structure. However, as is reflected in Table 2, the coefficient values may be expected to align with those of the other countries for extended horizons.

\subsection{Extended horizon and alternative dependent variables}

Apart from running regression (23) on longer horizons, an interesting extension of the framework is to change the definition of the dependent variable. The definition of the debt ratio has not been an issue, but questions arise regarding its relevance for the observed estimates. It has throughout been defined as the sum of long-term debt and current liabilities, but as discussed earlier, several other definitions can be presented which explain capital structure adequately. Hypothesis (vi), the ranking hypothesis, will be examined simultaneously. Table 4 displays the normalized coefficients for four different definitions of the dependent variable and two time horizons ${ }^{14}$. Three general results are noticeable. First, the five-year effect of stock returns on debt-ratio changes is greater than that of the one-year effect. Second, stock-return dependence of the debt ratio is reduced when the debt-ratio definition becomes narrower and more concentrated, reaching a low for the book-value ratio. Bearing in mind that the short-term financing products should enable the easiest means of counteracting short-term shocks to the preferred market-value debt ratio, one should expect the broad definition to be least sensitive to stock returns. The results are contrary to hypothesis (vi). Thirdly, the correlation of book-value debt

13 Various other specifications were tried, both to explain debt ratio and debt-ratio changes, all of which produced similar effects. Following Welch (2004), a non-linear specification was tried:

$\mathrm{D}_{\mathrm{t}+\mathrm{k}}-\mathrm{D}_{\mathrm{t}}=\beta_{1}+\beta_{2} \Delta \mathrm{D}_{\mathrm{t}, \mathrm{t}+\mathrm{k}}^{\mathrm{I}}+\Sigma^{\mathrm{N}}{ }_{\mathrm{i}}\left(\beta_{\mathrm{i}} \mathrm{V}_{\mathrm{t}, \mathrm{t}+\mathrm{k}}^{\mathrm{i}}+\gamma_{\mathrm{i}} \mathrm{V}_{\mathrm{t}, \mathrm{t}+\mathrm{k}}^{\mathrm{i}}\left(\Delta \mathrm{D}_{\mathrm{t}, \mathrm{t}+\mathrm{k}}^{\mathrm{I}}\right)\right)+\Sigma^{\mathrm{M}}{ }_{\mathrm{j}}\left(\beta_{\mathrm{j}} \mathrm{V}_{\mathrm{t},}^{\mathrm{j}}+\gamma_{\mathrm{j}} \mathrm{V}_{\mathrm{t}, \mathrm{t}}^{\mathrm{j}}\left(\Delta \mathrm{D}_{\mathrm{t}, \mathrm{t}+\mathrm{k}}^{\mathrm{I}}\right)\right)+\varepsilon_{\mathrm{t}+\mathrm{k}}$, where $\Delta D_{t, t+k}^{I}=D_{t, t+k}^{I}-D_{t}$. Although a few variables did not reach the same statistical significance as in Welch (2004), the estimated equation had similar explanatory power, variables had the same signs and most importantly, the implied debt ratio had similar measured economic influence $(8.54 \%$ vs. $7.38 \%)$. However, apart from the UK and US cases, $\Delta \mathrm{D}_{\mathrm{t}, \mathrm{t}+\mathrm{k}}^{\mathrm{I}}$ tended to be insignificant.

14 Here the term "normalized" means multiplying the coefficient with one standard deviation of the variable to obtain the magnitude of influence. 
ratio with stock return is lower than that of any of the market-value debt- ratio definitions. Yet, the market-oriented countries emerge with greater stock-return significance and higher coefficients for the one-year case. These three features also appear in Table 5.

Table 5 presents a collection of coefficient estimates presenting the past debt ratio in regression (9) across three time horizons and four debt-ratio definitions ${ }^{15}$. Three features stand out. First, there seems to be an increasing tendency towards debt-ratio readjustment as the time horizon is extended, except in the cases of Germany and Japan. Secondly, in many cases the long-term debt ratio seems to have more readjustment tendencies than other type of debt, which supports the findings in Table 4 but is at odds with hypothesis (vi). Thirdly, the book-value debt ratio shows most persistence towards past debt ratios and, crucially, in the bank-oriented countries for all three time horizons, again supporting the outcome in Table 4. In other words, the book-value debt ratio tends not to fluctuate in accordance with stock returns in the short run (one year) but does so increasingly over longer periods (five years). This is not surprising, as improved returns are bound to have effects on the book-value debt ratio in the long term. However, over such periods the debtratio target might have shifted from the past debt levels. These features could be interpreted as reflecting management's preoccupation with accounting values and book targets of debt ratios, rather than the market-value debt ratio.

Table 5 shows how, for extended horizons, the tendency to revert to the old bookvalue debt ratio generally decreases somewhat and the influence of stock returns improves to some degree. It seems that in the bank-oriented countries, past debt ratios are more useful in explaining future book-value debt ratios than is the case elsewhere. In contrast, firms in the market-oriented countries seem to let their book values adjust in accordance with stock-price behaviour. This is consistent with the book-value hypothesis (vii), and effectively means that accounting practices in each country matter. Wald (1999) finds support for this and claims German and Japanese accounting rules adhere more to historically based valuation. ${ }^{16}$ Another factor is market timing, if this is practised in the market-oriented countries. If so, the book value of equity will correlate with the stock price and the book-value debt ratio will respond more to stock returns and the implied debt ratio.

15 Convergence over time is denoted with "+" and divergence with "-".

16 Evidence was also found for this when estimating correlations between debt ratios and their past values, which proved to be higher for the bank-oriented countries. 
Table 4. Effects of Stock Returns $\left(D_{t, t+k}^{I}-D_{t}\right)$ on Debt Ratio Changes $\left(D_{t+k}-D_{t}\right)$ in \%, where $D_{t}=d_{t} /\left(d_{t}+e_{t}\right)$

\begin{tabular}{|c|c|c|c|c|c|c|c|c|}
\hline Abreviation & 1-year horizon & US & Japan & Germany & France & Italy & UK & Canada \\
\hline$D_{t}: d_{t}=c_{t}+l_{t}$ & Debt as current and long & $10.24^{* * *}$ & $2.80^{* *}$ & $1.35^{* *}$ & $8.24^{* * *}$ & $7.00 * * *$ & $9.38^{* * *}$ & $5.41^{* * *}$ \\
\hline$D_{t}: d_{t}=s_{t}+l_{t}$ & Debt as short and long & $8.96^{* * *}$ & $2.90^{* *}$ & $2.74^{* *}$ & $7.74^{* * *}$ & $6.40^{* * *}$ & $8.19^{* * *}$ & $5.04^{* * *}$ \\
\hline $\mathrm{D}_{\mathrm{t}}: \mathrm{d}_{\mathrm{t}}=\mathrm{l}_{\mathrm{t}}$ & Debt as long & $7.21 * * *$ & $2.90^{* * *}$ & $2.31^{* * *}$ & $6.45^{* * *}$ & $5.25^{* * *}$ & $5.06^{* * *}$ & $4.42^{* * *}$ \\
\hline $\mathrm{D}^{\mathrm{b}}: \mathrm{d}_{\mathrm{t}}=\mathrm{c}_{\mathrm{t}}+\mathrm{l}_{\mathrm{t}}$ & $\begin{array}{l}\text { Debt as current and long } \\
\text { book value }\end{array}$ & $18.35^{* * *}$ & 0.43 & $1.99 * *$ & 1.25 & 1.23 & $2.64^{* *}$ & $3.15^{* *}$ \\
\hline Abreviation & 5-year horizon & US & Japan & Germany & France & Italy & UK & Canada \\
\hline$D_{t}: d_{t}=c_{t}+l_{t}$ & Debt as current and long & $15.12^{* * *}$ & $9.35^{* * *}$ & $9.30^{* * *}$ & $11.79^{* * *}$ & $12.76^{* * *}$ & $12.69^{* * *}$ & $11.82^{* * *}$ \\
\hline$D_{t}: d_{t}=s_{t}+l_{t}$ & Debt as short and long & $12.50 * * *$ & $8.35^{* * *}$ & $9.07^{* * *}$ & $9.65^{* * *}$ & $12.41^{* * *}$ & $10.69^{* * *}$ & $9.23^{* * *}$ \\
\hline$D_{t}: d_{t}=l_{t}$ & Debt as long & $9.68^{* * *}$ & $9.11^{* * *}$ & $8.40^{* * *}$ & $7.17^{* * *}$ & $10.26^{* * *}$ & $6.46^{* * *}$ & $8.31^{* * *}$ \\
\hline $\mathrm{D}^{\mathrm{b}}{ }_{\mathrm{t}}: \mathrm{d}_{\mathrm{t}}=\mathrm{c}_{\mathrm{t}}+\mathrm{l}_{\mathrm{t}}$ & $\begin{array}{l}\text { Debt as current and long } \\
\text { book value }\end{array}$ & $10.28 * *$ & $2.08 * *$ & $6.69 * *$ & $4.47^{* *}$ & $5.72 * *$ & $5.08^{* *}$ & $5.34 * *$ \\
\hline
\end{tabular}

c, l, s, d and $\mathrm{D}^{\mathrm{b}}{ }_{\mathrm{t}}$ denote current liabilities, long \& short term debt, debt and the book value debt ratio respectively

Two asterisks reflect 95\% statistical significance and a third one added reflects a dominating economic influence on the debt ratic The coefficients are normalized on the variable standard deviation and presented in percentages 
Table 5. Debt Ratio Target Readjustment in \% Over Different Horizons

\begin{tabular}{|c|c|c|c|c|c|c|c|}
\hline Debt definition & US & Japan & Germany & France & Italy & UK & Canada \\
\hline \multicolumn{8}{|l|}{ Current and long } \\
\hline 1 year & 2.80 & 37.90 & 56.80 & 9.90 & 9.40 & 6.00 & 32.00 \\
\hline 3 years & $9.00+$ & $20.00-$ & $26.20-$ & $20.30+$ & $24.50+$ & $13.90+$ & $21.60-$ \\
\hline 5 years & $15.80+$ & $18.90-$ & $24.30-$ & $27.20+$ & $29.10+$ & $20.90+$ & $27.90+$ \\
\hline \multicolumn{8}{|l|}{ Short and long } \\
\hline 1 year & -2.20 & 40.90 & 50.60 & 2.00 & 8.30 & -1.60 & 31.70 \\
\hline 3 years & $4.50+$ & $13.40-$ & $14.60-$ & $6.80+$ & $11.60+$ & $-1.10+$ & $16.90-$ \\
\hline 5 years & $12.60+$ & $8.80-$ & $11.80-$ & $11.20+$ & $16.20+$ & $0.10+$ & $23.80+$ \\
\hline \multicolumn{8}{|l|}{ Long } \\
\hline 1 year & 7.50 & 30.60 & 50.30 & 5.50 & 6.80 & 8.70 & 33.40 \\
\hline 3 years & $14.00+$ & $8.80-$ & $13.60-$ & $13.00+$ & $7.40+$ & $11.20+$ & $19.20-$ \\
\hline 5 years & $20.40+$ & $11.40+$ & $11.00-$ & $18.30+$ & $11.30+$ & $18.40+$ & $27.40+$ \\
\hline Book debt ratio & US & Japan & Germany & France & Italy & UK & Canada \\
\hline \multicolumn{8}{|l|}{ Current and long } \\
\hline 1 year & 51.20 & 90.80 & 85.80 & 92.10 & 95.90 & 68.20 & 64.60 \\
\hline 3 years & $45.30-$ & $83.70-$ & $75.20-$ & $84.10-$ & $88.00-$ & $62.10-$ & $57.40-$ \\
\hline 5 years & $45.60+$ & $80.80-$ & 70.90 - & 78.70 - & $83.00-$ & $61.80-$ & $57.50+$ \\
\hline
\end{tabular}




\section{Conclusions}

Leverage behaviour is driven by similar factors in all the G-7 countries. However, the conventional theories have more strongholds in the market-oriented countries and Japan through more persistent debt-ratio influence of firm-specific characteristics. Stock returns have dominating effects on capital structure which management generally chooses not to counteract. The implied debt ratio absorbs crucial influence from the trade-off theory proxies, most severely in the bankoriented countries. The book-value debt ratios, on the other hand, show dependence on past debt-ratio values. This characteristic is stronger in the bank-oriented countries, possibly due to weaker links between accounting practices and market valuation and less market influence on the timing of equity issuing. It is proposed, accordingly, that corporate management is more concerned with book-value debtratio targets than their market-value counterparts. The motive underlying such preference is presumed to be the stable nature of accounting values and their signalling value. Secondly, it is argued that market-value debt ratio loses meaning and credibility as a target indicator under severe stock-price fluctuations. Correspondingly, management might favour keeping the market-value debt ratio within confidence intervals or restricting it to a flexible target.

The results presented provide evidence for a fluctuating debt ratio, whether targeted or not, and fall in with those presented by Welch (2004), Graham and Harvey (2001) and partially Myers (2001). The volatile nature of the market-value debt ratio might discredit it as a practical benchmark for business purposes and reduce its value as an optimising target. Actually, management seems to allow market-value debt-ratio fluctuation but might, all the same, keep a watchful eye on the debt-ratio development over time. Consequently, firms dealing with financing decisions are ready to tolerate a floating debt ratio within certain confidence limits, only to be acted on when drifting to extreme boundaries. This observation gives rise to a conditional floating debt-ratio target and a target zone. As a result, the observed tendency of long-run debt ratio to revert to prior levels could be explained on such grounds. Further, target zones leave space for management to promote other financial priorities than debt-ratio targeting, as is suggested by the survey results of Graham and Harvey (2001). 


\section{Appendix - Variable definitions:}

\begin{tabular}{|c|c|}
\hline Variable & $\begin{array}{l}\text { Definition (numbers quoted are DataStream reference } \\
\text { numbers) }\end{array}$ \\
\hline $\mathrm{d}_{\mathrm{t}}$ & $\begin{array}{l}\text { A composition of three debt definitions were tried: Long- } \\
\text { term debt (03251), short-term debt (03051) and current } \\
\text { liabilities (03101) }\end{array}$ \\
\hline et & $\begin{array}{l}\text { Two types of equity definitions were used, mainly the } \\
\text { market value of equity consisting of number of shares times } \\
\text { the end-of-year closing price (08001). The other definition } \\
\text { used for the book-value debt ratio was common equity } \\
(03501)\end{array}$ \\
\hline $\mathrm{D}_{\mathrm{t}}$ & Actual Debt ratio: $d_{t} /\left(d_{t}+e_{t}\right)$ \\
\hline $\mathrm{D}_{\mathrm{t}, \mathrm{t}+\mathrm{k}}$ & Implied debt ratio: $d_{t} /\left(e_{t}\left(1+x_{t, t+k}\right)+d_{t}\right)$ \\
\hline $\mathrm{X}_{\mathrm{t}, \mathrm{t}+\mathrm{k}}$ & Stock returns, represented by a return index (data type RI) \\
\hline$\Delta \mathrm{d}_{\mathrm{t}, \mathrm{t}+\mathrm{k}}$ & $d_{t, t+k}-d_{t}$ \\
\hline$\Delta \mathrm{e}_{\mathrm{t}, \mathrm{t}+\mathrm{k}}$ & $e_{t, t+k}-e_{t}$ \\
\hline Log return volatility & Standard deviation of returns from $t-1$ to $t$, logged \\
\hline Log firm volatility & $\begin{array}{l}\text { Return volatility times } \mathrm{e} /(\mathrm{e}+\mathrm{d}) \text {, logged. This definition of } \\
\text { business volatility was substituted for the one above but } \\
\text { gave similar results }\end{array}$ \\
\hline Stock return & “ $\left(1+\mathrm{x}_{\mathrm{t}, \mathrm{t}+\mathrm{k}}\right)$ " as used in $\mathrm{D}^{\mathrm{I}}$ computations \\
\hline Profitability/assets & $\begin{array}{l}\text { Operating income }(01250) \text { divided by assets (02999), filtered } \\
\text { between } 5 \% \text { and } 95 \% \text { distribution interval }\end{array}$ \\
\hline Profitability/sales & Same as above but divided by sales (01001) \\
\hline Tax rate & $\begin{array}{l}\text { Income tax (01451) divided by net income (01551) plus } \\
\text { income tax, filtered between }-100 \% \text { and }+200 \%\end{array}$ \\
\hline $\begin{array}{l}\text { Research and } \\
\text { development }\end{array}$ & $\begin{array}{l}\text { R\&D expense divided by sales (01001) and filtered between } \\
5 \% \text { and } 95 \% \text { distribution levels }\end{array}$ \\
\hline Industry deviation & $\begin{array}{l}\text { The difference between the } D_{t} \text { of a firm and the } D_{t} \text { average of } \\
\text { the industrial category the firm belongs to according to a } \\
\text { three-digit industry SIC code. }\end{array}$ \\
\hline
\end{tabular}




\begin{tabular}{|l|l|}
\hline Tangibility & $\begin{array}{l}\text { Property, plant and equipment (02501) divided by assets } \\
\text { (02999) }\end{array}$ \\
\hline Log assets & Total assets (02999) adjusted to 2003 levels using the CPI. \\
\hline Log sales & Sales (01001), logged. \\
\hline $\begin{array}{l}\text { Log relative market } \\
\text { capitalization }\end{array}$ & $\begin{array}{l}\text { Market value of equity (08001) divided by the price level of } \\
\text { the relevant stock market index. }\end{array}$ \\
\hline Market-to-book ratio & $\begin{array}{l}\text { Market value of equity divided by the book value of equity, } \\
\text { filtered between the } 5 \% \text { and } 95 \% \text { distribution interval }\end{array}$ \\
\hline
\end{tabular}

\section{Bibliography.}

Baker, M., \& Wurgler, J. (2002). Market timing and capital structure, Journal of Finance, 57, 1-32.

Benartzi, S. \& Thaler, R. H. (2001). Naïve diversification strategies in defined contribution saving plans. American Economic Review, 91, 79-98.

Brealey, R. A., \& Myers, S. C. (2003). Principles of Corporate Finance, (MacGrawHill/Irwin, New York).

Frank, M. Z., \& Goyal, V. K. (2003). Testing the pecking order theory of capital structure. Journal of Financial Economics, 67, 217-248.

Graham, J. R., \& Harvey, C. (2001). The theory and practice of corporate finance: Evidence from the field. Journal of Financial Economics, 60, 187-243.

Harris, M., \& Raviv, A. (1991). The theory of capital structure. Journal of Finance, 41, 297-355.

Jensen, M. C. (1986). Agency costs of free cash flow, corporate finance and takeovers. American Economic Review, 76, 323-339.

Jensen, M. C., \& Meckling, W. (1976). Theory of the firm: Managerial behaviour, agency costs and capital structure. Journal of Financial Economics, 3, 305-360.

Leland, H., \& Pyle, D. (1977). Information asymmetrics, financial structure and financial intermediation. Journal of Finance, 44, 771-787.

Miller, M. H. (1977). Debt and taxes. Journal of Finance, 32, 261-276.

Modigliani, F., \& Miller, M. H. (1958). The costs of capital, corporation finance and the theory of investment. American Economic Review, 48, 261-297.

Myers, S. C. (1977). Determinants of corporate borrowing. Journal of Financial Economics, 5, 147-175.

Myers, S. C. ( 2001). Capital Structure. Journal of Economic Perspectives, 15( 2), 81-102. 
Myers, S. C. (2003). Financing of Corporations. In G. M. Constantinides, M. Harris and R. Stulz, (Eds.), Handbook of the Economics of Finance (pp. 215-247). Elsevier, North Holland.

Myers, S. C., \& Majluf, N. S. (1984). Corporate financing and investment decisions when firms have information that investors do not have. Journal of Financial Economics, 13, 187-221.

Rajan, R. G., \& Zingales, L. (1995). What do we know about capital structure? Some evidence from international data. Journal of Finance, 50, 1422-1460.

Ross, S. (1977). The determination of financial struture: The incentive signalling approach. Bell Journal of Economics, 8, 23-40.

Shyam-Sunder, L., \& Myers, S. C. (1999). Testing static trade-off against pecking order models of capital structure. Journal of Financial Economics, 51, 219-244.

Smith, C., \& Warner, J. (1979). On financial contracting. Journal of Financial Economics, 7, 117-161.

Spence, A. M. (1973). Job market signalling. Quarterly Journal of Economics, 87, 355379.

Wald, J. K. (1999). How firm characteristics affect capital structure: An international comparison, Journal of Financial Research, 22, 161-187.

Welch, I. (2004). Capital structure and stock returns, Journal of Political Economy, 112 (1), 106-131. 